\title{
Calixarene Derivatives for (Nano)Biotechnologies
}

\author{
Roman Rodik, Mykola Poberezhnyk, and Vitaly Kalchenko@ \\ The article is devoted to 75th anniversary of Academician A. Yu. Tsivadze
}

Institute of Organic Chemistry, National Academy of Sciences of Ukraine, 02660 Kyiv, Ukraine

${ }^{\circledR}$ Corresponding authorE-mail: vik@ioch.kiev.ua

\begin{abstract}
This review summarizes the author's research in the field of bio-medical application of modified calixarenes as well as their nano-associates. The paper includes results of design and investigation of the calixarenes as intracellular transport modulators of $\mathrm{Ca}$ and Na cations, as well as effective and selective phosphatases inhibitors. The antibacterial and anticoagulant properties of series water-soluble positively or negatively charged calixarenes are described. Also, utilization of calixarenes for hierarchical formation of nanoparticles for nanobiotechnological application (DNA transfection and bio-imaging) is discussed.
\end{abstract}

Keywords: Calixarenes, nanobiotechonogies, intracellular transport, phosphatases inhibitors, DNA transfection, bio-imaging.

\section{Производные каликсаренов Аля (нано)биотехнологий}

\author{
Р. Родик, Н. Побережник, В. Кальченко \\ Статья посвящена 75-летию со дня рождения академика А. Ю. Цивадзе
}

Институт органической химии, Национальная академия наук Украинь,, 02660 Киев, Украина

${ }^{\circledR}$ E-mail:vik@ioch.kiev.ua

\begin{abstract}
В работе представлень результаты дизайна и исследования каликсаренов как внутриклеточных модуляторов транспорта катионов Са и Na, а также эффективных и селективных ингибиторов фосфатаз. Описаны антибактериальные и антикоагулянтные свойства серии водорастворимых положительно или отрицательно заряженных каликсаренов. Обсуждается также использование каликсареновых наночастии для трансфекиии ДНК и создания флуоресиентных маркеров для медицинской диагностики.
\end{abstract}

Ключевые слова: Каликсарены, нанобиотехнологии, внутриклеточный транспорт, ингибиторы фосфатаз, трансфекция ДНК, флуоресцентные маркеры. 


\section{Introduction}

Calixarenes are synthetically readily available nanosized macrocyclic compounds ${ }^{[1]}$ which possess an exceptional three-dimensional cone-shaped topology. The upper and the lower rim of calixarenes can be grafted with a large variety of bio affine groups, which may carry many bio-inspired functions. Due to unique receptor properties of the calixarene family concerning bio-cation, bio-anion, bio-molecules and biopolymers a wide possibilities of its bio-medical application are discussed. ${ }^{[2]}$ Bio-medical potential of the calixarenes: the antiviral, bactericidal, antithrombothic, antituberculosis, anticancer activities, transfection ability, specific protein complexation, enzyme mimic, membranotropic properties etc., is well documented. ${ }^{[3]}$

This review summarizes the author's research of the bio-medical application of modified calixarenes as well as their nano-associates. The paper includes results of design and investigation of the calixarenes as intracellular transport modulators of $\mathrm{Ca}$ and $\mathrm{Na}$ cations, as well as effective and selective phosphatases inhibitors. The antibacterial and anticoagulant properties a series of water-soluble positively or negatively charged calixarenes are described. Also, utilization of calixarenes for hierarchical formation of nanoparticles for nanobiotechnolical application (DNA transfection and bio-imaging) is discussed.

\section{Calixarenes Modulators of Contractile Function and $\mathrm{Ca}^{2+}$ Ions Exchange in Smooth Muscle Cells}

\section{Inhibition of Calcium Pumps}

The effect of sulfonylamidine calixarenes on the activity of calcium pumps of smooth muscle cells was investigated. [4-6] It was shown that calixarene-tetrasulfonylamidine $\mathbf{1}$ reduces the transport activity of the ruthenium red insensitive, oxalate-stimulated, $\mathrm{Mg}^{2+}$, ATP-dependent calcium pump of sarcoplasmic reticulum by $75 \%$. A similar result was found for the $\mathrm{Mg}^{2+}$, ATP-dependent calcium pump of the plasma membrane (PM, $\left.\mathrm{I}_{0.5}=34.6 \mu \mathrm{M}\right)$. On the other hand, the ruthenium red sensitive $\mathrm{Ca}^{2+}$-transport in mitochondria was not affected by calixarene $\mathbf{1}$ as well as other membrane pumps (Figure 1). ${ }^{[5,6]}$

Further investigation of macrocycles 2, 3 showed that di-substituted calixarenes as well as model compounds $\mathbf{4}$ and $\mathbf{5}$ possess less activity (Table 1). So, inhibition efficiency of the $\mathrm{Ca}^{2+}, \mathrm{Mg}^{2+}$-ATPase ofPMbythe sulfonylamidine calix[4] arenes correlates with quantity of phenylsulfonylamidine groups on the calixarene upper rim. It should be noted that the inhibitory effects of the studied calix[4]arenes also depended on the relative location of phenylsulfonylamidine groups on the upper rim of the calix[4]arene "bowl". ${ }^{[7]}$

Calixarene-bisamide $\mathbf{6}$ in concentration $100 \mu \mathrm{M}$ acts multidirectionally on the functionally different $\mathrm{Mg}^{2+}$ dependent ATP-hydrolase enzymatic systems. Calixarene 6 activates effectively the actomyosin ATPase $\left(K_{a}=52 \pm 11\right.$ $\mu \mathrm{M})$. Also, 6 effectively reduces basal $\mathrm{Mg}^{2+}$-ATPase activity, insignificantly activating $\mathrm{Na}^{+}, \mathrm{K}^{+}$-ATPase, but has no influence on transporting $\mathrm{Ca}^{2+}, \mathrm{Mg}^{2+}$-ATPase activity of plasmatic membranes. ${ }^{[6]}$ The results of the comparative investigation of $\mathbf{6}$ are shown in the Figure 2.
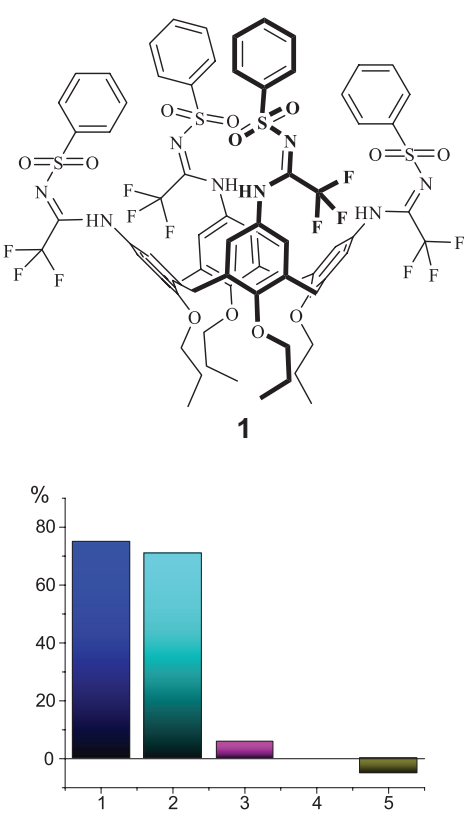

Figure 1. Inhibition of myometrium smooth muscle cells transporting ATP-ases by calixarene $1(0.1 \mathrm{mM})$ : $1-\mathrm{Mg}^{2+}$, ATP-dependent $\mathrm{Ca}^{2+}$ accumulation in the miometrial sarcoplasmic reticulum; $2-\mathrm{Mg}^{2+}$, ATP-dependent calcium pump of the plasma membrane; 3 - ouabain-suppressed $\mathrm{Na}^{+}, \mathrm{K}^{+}$-ATPase; $4-\mathrm{Mg}^{2+}$, ATP-dependent $\mathrm{Ca}^{2+}$ accumulation in the mitochondria; $5-\mathrm{Ca}^{2+}$-independent $\mathrm{Mg}^{2+}$-ATPase ("basal" $\mathrm{Mg}^{2+}$-ATPase).
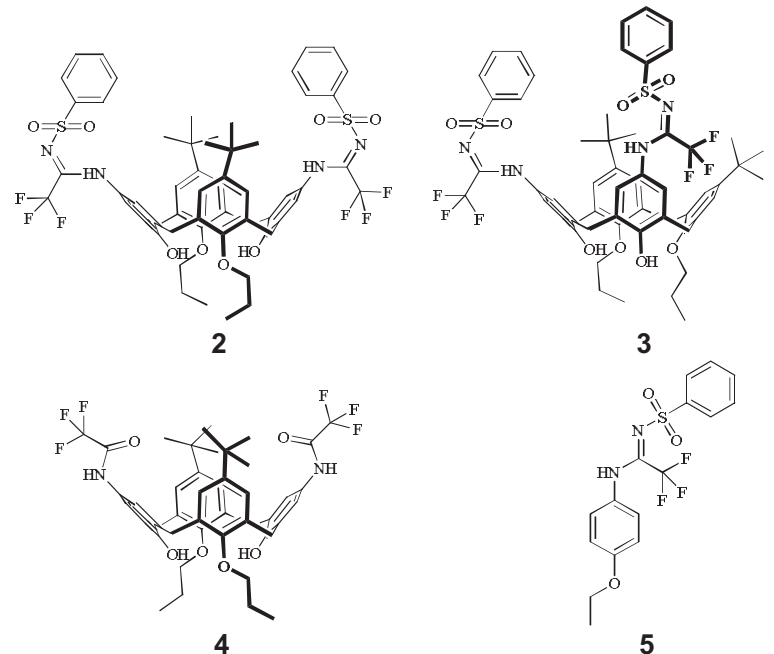

Table 1. Inhibitory effect of the sulfonylamidine calix[4]arenes 1-3, bisamide calix[4]arene 4 and the model compound $\mathbf{5}$ on specific enzymatic activity of $\mathrm{Ca}^{2+}, \mathrm{Mg}^{2+}$-ATPase of plasma membrane of myometrium cells.

\begin{tabular}{ccc}
\hline Calix[4]arene & $\begin{array}{c}\text { Inhibition } \\
\text { coefficient, } \\
\mathrm{I}_{0.5}, \mu \mathrm{M}\end{array}$ & $\begin{array}{c}\text { The remaining enzymatic } \\
\text { activity at concentration } \\
100 \mu \mathrm{M}, \%\end{array}$ \\
\hline $\mathbf{1}$ & $20.2 \pm 0.5$ & $25.0 \pm 0.3$ \\
$\mathbf{2}$ & $53.4 \pm 3.6$ & $38.5 \pm 1.9$ \\
$\mathbf{3}$ & $165 \pm 20$ & $54.1 \pm 0.6$ \\
$\mathbf{4}$ & - & $79.3 \pm 0.9$ \\
$\mathbf{5}$ & - & $90.7 \pm 2.4$ \\
\hline
\end{tabular}



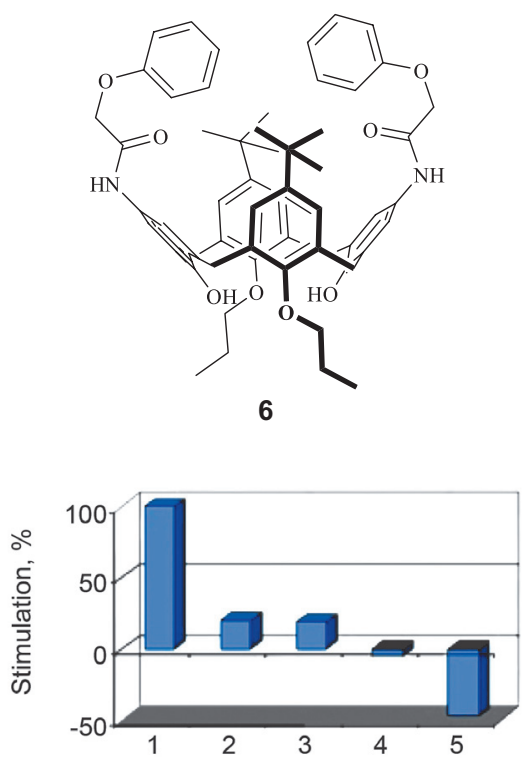

Figure 2. Influence of transporting ATP-ases of smooth muscle cells of miometrium by calixarene 6: $1-\mathrm{Mg}^{2+}$, ATP-dependent $\mathrm{Ca}^{2+}$ accumulation in the mitochondria; $2-\mathrm{Mg}^{2+}$, ATP-dependent $\mathrm{Ca}^{2+}$ accumulation in the miometrial sarcoplasmic reticulum; 3 - ouabain-suppressed $\mathrm{Na}^{+}, \mathrm{K}^{+}$-ATPase; 4 - $\mathrm{Mg}^{2+}$, ATP-dependent calcium pump of the plasma membrane; $5-\mathrm{Ca}^{2+}$-independent $\mathrm{Mg}^{2+}$-ATPase ("basal" $\mathrm{Mg}^{2+}$-ATPase).

\section{Calixarene Effectors of Sodium-Potassium Pump}

Effect of calix[4]arenes 7, 9, 10 functionalized by aminophosphonic acid, hydroxyphosphonic acid, and methylene-bisphosphonic acid groups on enzymatic activity of oubain-sensitive $\mathrm{Na}^{+}, \mathrm{K}^{+}$-ATPase and oubain resistant basal $\mathrm{Mg}^{2+}$-ATPase was studied. ${ }^{[8,9]}$
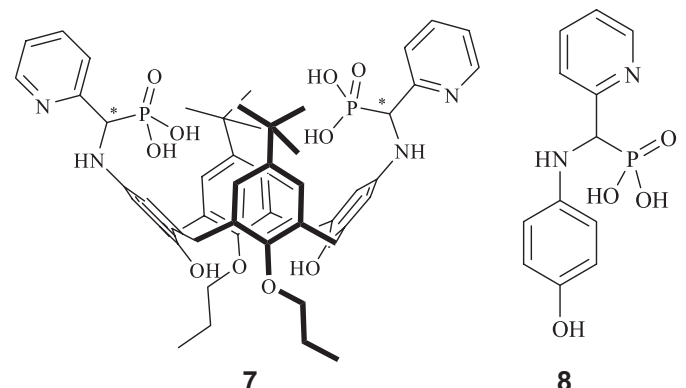

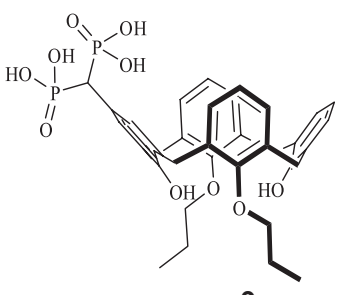

9

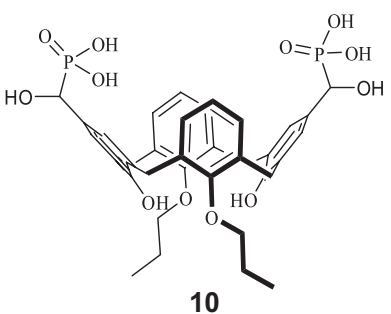

10
This pump indirectly regulates intracellular concentration of $\mathrm{Ca}^{2+}$ due to conjugate action with CalciumSodium exchanger of PM. It was found that calixarene phosphonic acids 7, 9, 10 at concentration of $100 \mu \mathrm{M}$ inhibited enzymatic activity of $\mathrm{Na}^{+}, \mathrm{K}^{+}$-ATPase by $86-98 \%$ and had almost no influence on activity of $\mathrm{Mg}^{2+}$-ATPase. These calixarenes are more efficient than ouabain in reduction of enzymatic activity of the sodium pump (Table 2). In the presence of calixerenes 7, 9, 10 the value of the apparent constant of inhibition $\mathrm{I}_{0.5}$ was $<0.1 \mu \mathrm{M} .^{[8]}$ The model compound 8 (a fragment of the calixarene 7) in concentrations $10 \mathrm{nM}-0.4 \mathrm{mM}$ practically didn't change the enzymatic activities as $\mathrm{Na}^{+}, \mathrm{K}^{+}$-ATPase and basal $\mathrm{Mg}^{2+}$ ATPase.

Hence the influence of calixarene 7 on the $\mathrm{Na}^{+}, \mathrm{K}^{+}-$ ATPase activity is caused by cooperative action of two fragments 8 on the calixarene scaffold. Calixarenes 7 and 9 increase affinity of the $\mathrm{Na}^{+}, \mathrm{K}^{+}$-ATPase to the cardiac glycoside ouabain. ${ }^{[9]}$

Table 2. Inhibition of activity of $\mathrm{Na}^{+}, \mathrm{K}^{+}$-ATPase of myometrium cell plasma membranes by the calixarenes 7, 9, 10 and ouabain.

\begin{tabular}{cccc}
\hline Inhibitors & $\begin{array}{c}\text { Full inhibition } \\
\text { concentration, } \mu \mathrm{M}\end{array}$ & $\begin{array}{c}\text { Pseudo constant } \\
\text { of inhibition, } \mathrm{I}_{0,5}, \\
\mathrm{nM}\end{array}$ & $\begin{array}{c}\text { Hill coefficient, } \\
\mathrm{n}_{\mathrm{H}}\end{array}$ \\
\hline $\mathbf{7}$ & $\sim 10$ & $54+6$ & $0.40+0.08$ \\
$\mathbf{9}$ & $\sim 10$ & $33+4$ & $0.38+0.06$ \\
$\mathbf{1 0}$ & 1000 & $98+8$ & $0.12+0.03$ \\
ouabain & 1000 & $21000+5000$ & $0.54+0.07$ \\
\hline
\end{tabular}

Further investigation showed, that alkylation of calixarene lower rim (derivatives $\mathbf{1 1}$ and 12) lead to loss of their activity. Probably, strong intramolecular hydrogen bonds $\mathrm{O}-\mathrm{H} \cdots \mathrm{OPr}$ at the lower rim stabilize the molecule $\mathbf{1 0}$ in the cone conformation and favor to high inhibition of $\mathrm{Na}^{+}$, $\mathrm{K}^{+}$-ATPase of plasma membrane myometrium cell. ${ }^{[9]}$

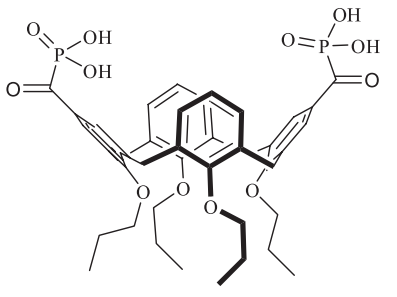

11

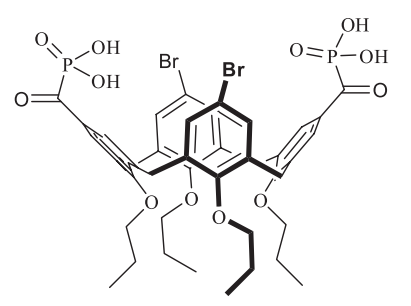

12

\section{Calixarenes Influence on $\mathrm{Ca}^{2+}$ Accumulation in Subcellular Structures}

Effects of calixarene chalconamides on $\mathrm{Mg}^{2+}$, ATPdependent $\mathrm{Ca}^{2+}$ transport in smooth muscle subcellular structures were also studied. ${ }^{[10]}$ The results are presented in Figures 3 and 4.

Calixarenes 13a and 13b stimulate $\mathrm{Ca}^{2+}$ accumulation in the mitochondria and don't have modulating effect on $\mathrm{Ca}^{2+}$ accumulation in the sarcoplasmic reticulum. It was also shown that model compound $\mathbf{1 5}$ does not modulate $\mathrm{Ca}^{2+}$ accumulation in the mitochondria and sarcoplasmic reticulum and 4'-acetamidochalcone 16 inhibits accumulation in the mitochondria by $65 \%$ and in the sarcoplasmic reticulum by $35 \%$. Acid 14 completely suppresses energy dependent $\mathrm{Ca}^{2+}$ accumulation both in the mitochondria and in sarcoplasmic reticulum. 

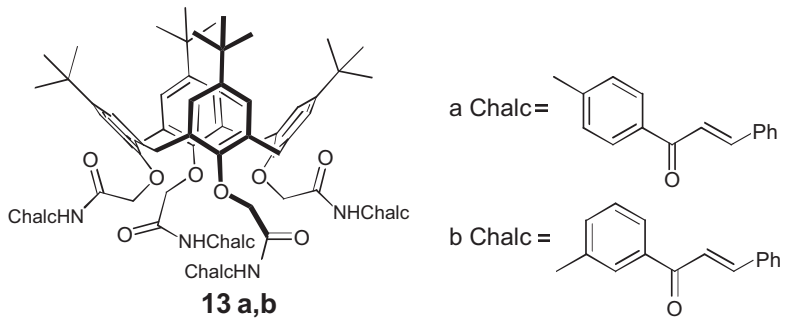

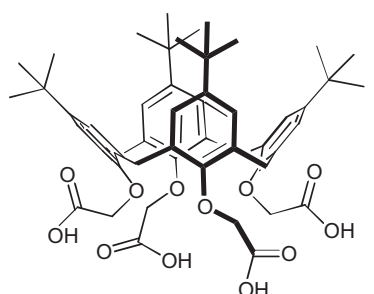

14<smiles>CC(=O)Nc1ccc(C(=O)/C=C/c2ccccc2)cc1</smiles>

16

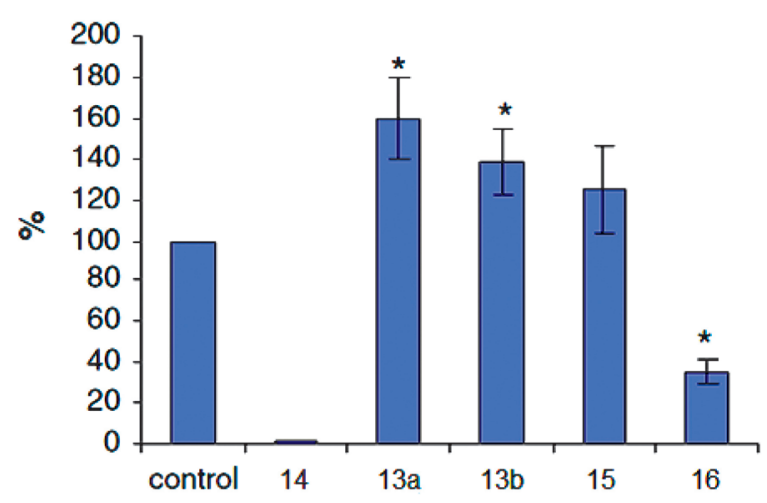

Figure 3. Calixarene 13-16 effects on $\mathrm{Mg}^{2+}$, ATP-dependent $\mathrm{Ca}^{2+}$ accumulation in rat uterus smooth muscle mitochondria.

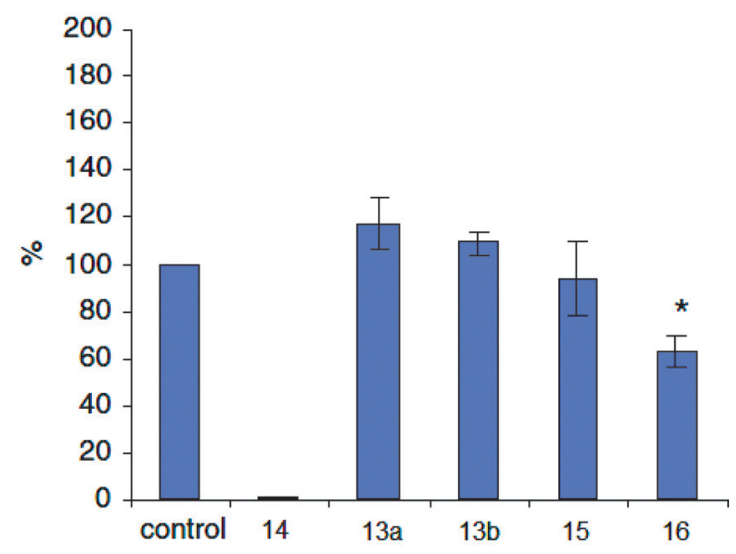

Figure 4. Calixarenes 13-16 effects on $\mathrm{Mg}^{2+}$, ATP-dependent $\mathrm{Ca}^{2+}$ accumulation in rat uterus smooth muscle sarcoplasmic reticulum.

\section{Myometrium Actomyosin and Myosin Inhibition}

It was shown that the calix[4]arene 9 bearing one methylene-bisphosphonic acid fragment inhibits the ATPase activity of myometrium actomyosin (inhibition coefficient $\left.\mathrm{I}_{05}=84 \pm 2 \mu \mathrm{M}\right)$ and myometrium myosin subfragment-1 $\left(\mathrm{I}_{0.5}=83 \pm 7 \mu \mathrm{M}\right) \mathrm{r}^{[1]}$ Investigation of calixarene $\mathbf{9}$ effects on myometrium myosin subfragment-1 ATPase showed that in a concentration of $10 \mu \mathrm{M}$ it almost didn't influence ATPase activity. The dose-dependent inhibition of myosin head ATPase was observed at growing calixarene 9 concentrations, and at $100 \mu \mathrm{M}$ the inhibiting effect $v$ s. control was $60 \pm 5 \%$. According to the linearized graph in Hill coordinates (Figure 5), inhibition coefficient $\mathrm{I}_{0.5}=83 \pm 7 \mu \mathrm{M}$.

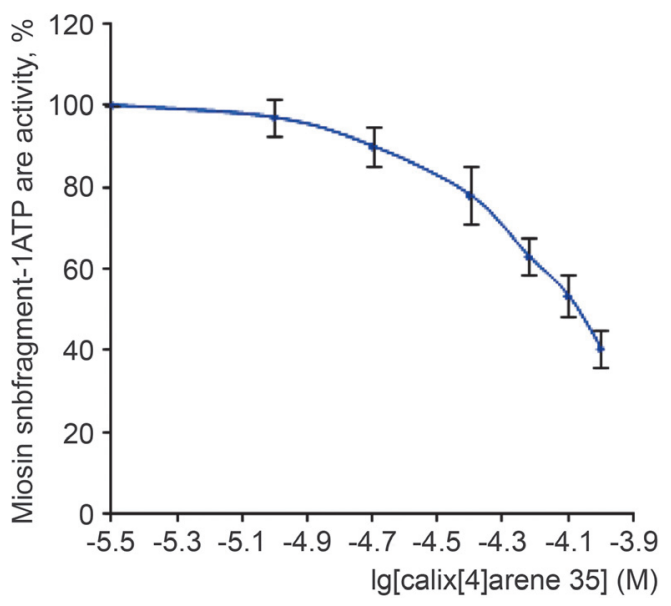

Figure 5. Catalytic titration of myosin subfragment-1 ATPase activity with calixarene 9 .

To understand the molecular mechanism of calixarene 9 inhibition of myosin subfragment-1 the molecular docking for the interaction of calixarene 9 (as a separate ligand or coupled with ATP) with myometrium myosin subfragment-1 in the presence of $\mathrm{Mg}^{2+}$ as a cofactor (Figure 6) was performed (Mg cation takes part in the binding of ATP to the active site, and in the process of its hydrolysis).

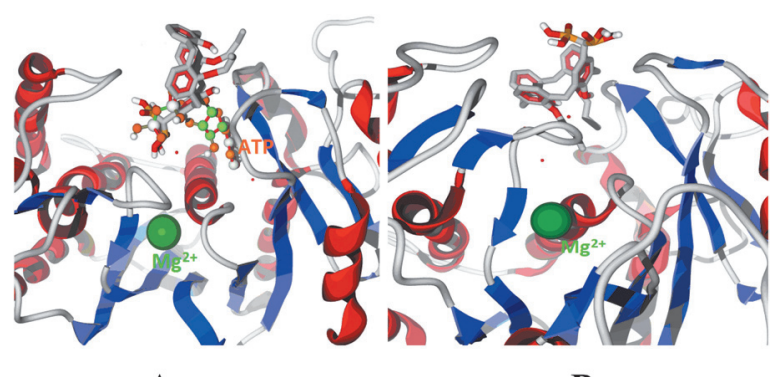

A

B

Figure 6. Docking of calixarene 9 as a separate ligand into the active site of myosin subfragment-1 (A) and docking of the paired ligand "9 + ATP" (B) in the presence of $\mathrm{Mg}^{2+}$ as a cofactor.

It was suggested that $\mathrm{Asp}_{320}, \mathrm{Asn}_{321}, \mathrm{Leu}_{676}$ and $\mathrm{Gln}_{678}$ may be involved in the coordination of the calixarene phosphonate groups. These data are obtained based on analysis of the docking of calixarene 9 into the ligand binding site of myosin subfragment-1. 


\section{Highly Effective Calixarene-based Phosphatase Inhibitors}

\section{Inhibitors of Alkaline Phosphatases}

Inhibition of nonspecific alkaline phosphatases is of significant current medical interest, since these enzymes catalyze the hydrolysis of phosphate monoesters, which are involved in a number of important biochemical pathways.

Calix[4]arenes 9 and $\mathbf{1 7}$ bearing one or two methylenebisphosphonic acid fragments displayed stronger inhibition of calf intestine alkaline phosphatase than model methylenebisphosphonic acid $\mathbf{1 8}$ or 4-hydroxyphenyl methylenebisphosphonic acids $19 .{ }^{[12]}$

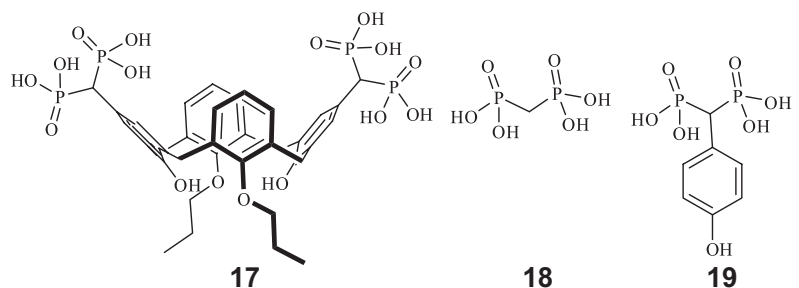

The inhibitory activities of the compounds 9, 17-19 were investigated in the calf intestine alkaline phosphatase catalyzed hydrolysis of $p$-nitrophenylphosphate. The influence of compounds 9, 17-19 on the enzyme activity is in agreement with mixed-type or partial mixed-type inhibition. The mechanism of catalysis by alkaline phosphatase includes formation of the enzyme-substrate complex, phosphoryl transfer from this complex to a nucleophilic serine group, the hydrolysis of the covalent phosphorylated enzyme intermediate, the formation of a non-covalent enzyme-phosphate complex and the release of inorganic phosphate (Figure 7).

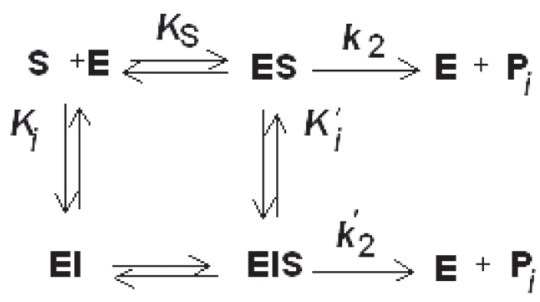

Figure 7. Schematic mechanism of alkaline phosphatase action and inhibition.

The dissociation constants of the enzyme inhibitor $K_{\mathrm{i}}$ and the enzyme-substrate inhibitor $K_{i}$ ' complexes with 9, 17$\mathbf{1 9}$ are presented in the Table 3.

The inhibitory activity of calixarene $\mathbf{1 7}$ is the consequence of the preorganization of two methylene-bisphosphonic acid moieties. The efficient coordination of $\mathbf{1 7}$ with the metal cations in the enzyme's active site and the additional van der Waals interactions brought about by the scaffold itself are probably responsible for its high activity.

Further investigations of inhibitory effect of chiral calixarene-aminophosphonic acids 20, 21 to alkaline phosphatase of different domestic animals were carried out. ${ }^{[13]}$
Table 3. Inhibition constants $K_{\text {, }}$ and $K_{i}^{\prime}$ for the inhibitors 9, 17-19 of calf intestine alkaline phosphatase.

\begin{tabular}{ccc}
\hline Inhibitor & $K_{i}, \mu \mathrm{M}$ & $K_{i}^{\prime}, \mu \mathrm{M}$ \\
\hline $\mathbf{9}$ & 2.5 & 46 \\
$\mathbf{1 7}$ & 0.38 & 2.8 \\
$\mathbf{1 8}$ & $67 \pm 5$ & $750 \pm 100$ \\
$\mathbf{1 9}$ & $22 \pm 4$ & $290 \pm 110$ \\
\hline
\end{tabular}

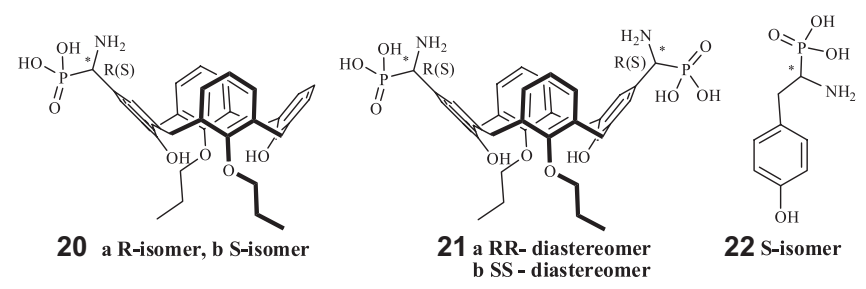

Compounds 20, 21 display almost identical affinities to bovine intestinal alkaline phosphatase (BIAP). But the inhibition of porcine kidney alkaline phosphatase (PKAP) is sensitive to the absolute configuration of the calixarene $\alpha$-aminophosphonic acids. The $K_{i}$ value for $S$-isomer $\mathbf{2 0 b}$ is about two times smaller than for its $R$-counterpart 20a. The enantioselectivity of the inhibition is drastically increased in bisaminophosphonic acids 21a,b. Namely, the $R, R$-isomer 21a binds to PKAP about 50 times stronger than the $S, S$ isomer $\mathbf{2 1 b}$, which corresponds to a difference in free energy of $2.3 \mathrm{kcal} / \mathrm{mol}$ (Table 4$)$.

Table 4. Inhibition constants $K_{i}$ and $K_{i}^{\prime}(\mu \mathrm{M})$ for the inhibition of PKAP by compounds 20, 21 and $(S)$-4-hydroxybenzyl-2aminomethylphosphonic acid 22. Free energies $\Delta G(\mathrm{kcal} / \mathrm{mol})$ for the formation of enzyme-inhibitor complexes of PKAP

\begin{tabular}{cccc}
\hline Inhibitor & $K_{i}$ & $K_{i}$, & $\Delta G_{1}$ \\
\hline 20a $(\boldsymbol{R})$ & $73 \pm 13$ & $540 \pm 90$ & -5.6 \\
20b $(\boldsymbol{S})$ & $32 \pm 5$ & $780 \pm 100$ & -6.1 \\
21a $(\boldsymbol{R} \boldsymbol{R})$ & $1.7 \pm 3$ & $130 \pm 30$ & -7.8 \\
21b $(\boldsymbol{S S})$ & $86 \pm 11$ & $610 \pm 210$ & -5.5 \\
22 (S) & $580 \pm 110$ & $6800 \pm 840$ & -4.4 \\
\hline
\end{tabular}

$0.1 \mathrm{M}$ tris-HCI buffer (pH 9), $23{ }^{\circ} \mathrm{C}, \Delta G=-\mathrm{RT} \ln \left(K_{\mathrm{i}}^{-1}\right)$.

So, the strength of the enzyme-inhibitor interactions is determined both by cooperative effects and the goodness of the fit of the chiral inhibitor to the chiral space around the binding site. To the best of our knowledge compound 21a is the first alkaline phosphatase inhibitor of $R$-aminophosphonic acid type that has an affinity for the enzyme in the micromolar range.

\section{Inhibitors of Protein Tyrosine Phosphatases (PTPs)}

The next stage of phosphatase survey was study a series of (thia)calix[4]arene phosphonous acids in inhibition of protein tyrosine phosphatases (PTP). Named enzymes regulate a number of biochemical processes which proceed 
through dephosphorylation of phosphotyrosine residues in proteins, including cell growth, differentiation, metabolism, and movement. Because of importance of the protein phosphorylation-dephosphorylation cycle in living cells, the activities of these enzymes are associated with diabetes, obesity, cancer and other human diseases.

Preliminary, inhibition of Yersinia protein tyrosine phosphatase by calix[4]arene and thiacalix[4]arene tetrakis(methylphosphonic) acids has been investigated. ${ }^{[14]}$ The kinetic studies revealed that $\mathbf{2 3}$ and $\mathbf{2 4}$ are potent competitive inhibitors of Yersinia PTP with inhibition constants 0.92 and $0.22 \mu \mathrm{M}$. It was found the phosphonate groups as well as macrocyclic structure is essential for the activities of these compounds. Model docking studies revealed similar binding mode for calixarene inhibitors covering the active site, with location of the phosphonate residues around the entry of the phosphotyrosine binding cavity.

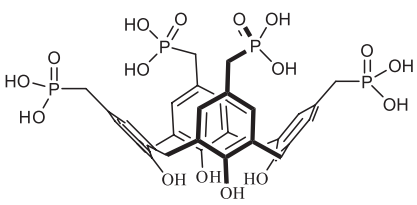

23

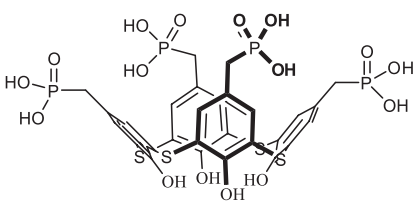

24
Protein tyrosine phosphatase 1B (PTP1B) belongs to the superfamily of PTPs and involves in insulin and leptin signal transduction by dephosphorylation of activated insulin receptor or leptin receptor-associated kinase, JAK2. As a negative regulator of insulin and leptin signalling, PTP1B is one of the most promising therapeutic targets for treatment of type 2 diabetes. ${ }^{[15]}$ Calix[4] arenes bearing methylene-bisphosphonic $\mathbf{9}$ and $\mathbf{1 7}$ or hydroxymethylenebisphosphonic 25 and 26 acid fragments at the wide rim of the macrocycle were studied as inhibitors of PTP1B. ${ }^{[16]}$

Next part of the study operated with calix[4]arene mono- and bis- $\alpha$-hydroxymethylphosphonic acids 27 and $10 .{ }^{[17]}$ The calixarene $\alpha$-ketophosphonous acids 28 and 29 were also investigated and it was found that these macrocycles are able to inhibit PTP1B with $\mathrm{IC}_{50}$ values in the micromolar range displaying lesser efficiency but selectivity over TC-PTP, MEG1, MEG2, SHP2, LAR and PTP- $\beta .{ }^{[18]}$ Some of the inhibitors showed $\mathrm{IC}_{50}$ values in the micromolar range and good selectivity in comparison with other protein tyrosine phosphatases such as TC-PTP, PTPb, LAR, and CD45 (Table 5). Kinetic studies indicated that the calix[4]arene derivatives influence PTP1B activity as slow-binding inhibitors. The $\alpha$-ketophosphonate moiety together with macrocyclic platform was supposed to bind to the active site of PTP1B by reversible slow-binding inhibition mechanism. Molecular docking performed on example of PTP1B indicated that hydroxymethylphosphonate fragment of the inhibitor $\mathbf{2 7}$ is able to mimic the binding of the substrate in the enzyme active site region. To clarify the mechanism of inhibition, the possible enzymeinhibitor complexes have been considered using several crystal structures of PTP1B and all stereoisomeric forms of the inhibitors.

In contrast to inhibition of alkaline phosphatases, better activity showed mono-substituted calixarene derivatives compared to disubstituted.

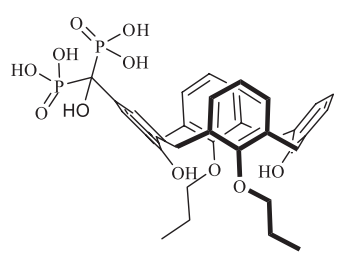

25
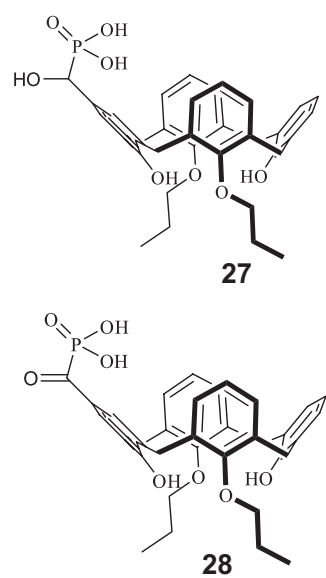

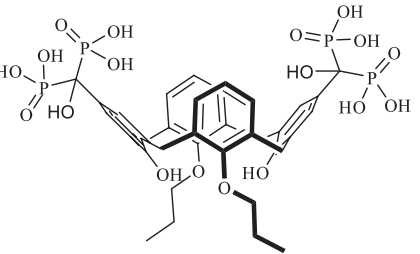

26

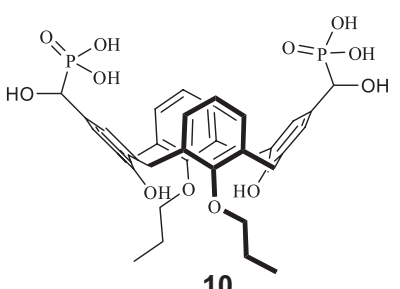

10

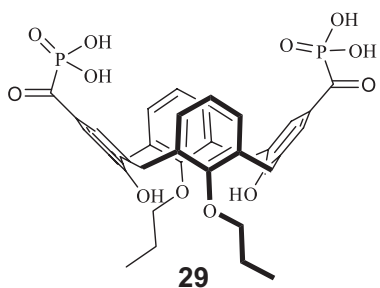

Last part of this systematic investigation involved tetrasubstituted thiacalix[4]arenes. It was demonstrated that the thiacalix[4]arene derivatives with covalently attached phosphonic acid monoester groups 30a,b exhibit strong submicromolar inhibition of PTP1B and selectivity over some other PTPs. ${ }^{[19]}$ Compound 30a is an approximately 11-fold more potent inhibitor of PTP1B as compared to TCPTP, Meg1, SHP2, and 8-fold more active towards Meg2. Molecular interactions between the phosphonate monoesters and HSA were detected to demonstrate a possible mechanism of their bioavailability. The presented data provide new insight into properties of the phosphonate monoesters creating the basis for further development of potent macrocyclic inhibitors of PTP1B.

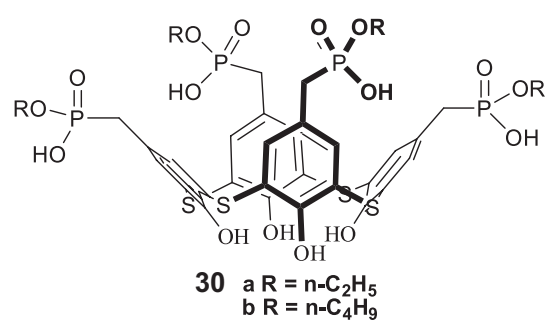

\section{Anticoagulant and Antithrombotic Properties of Calixarenes}

Inappropriate coagulation of blood (thrombosis) may occur within the circulatory system in pathological states such as atherosclerosis or in response to a variety of insults, including surgery and implantation of medical devices. Prevention of thrombosis is considered a crucial part of the treatment regimen for patients at risk for the thrombi development.

In general, agents affecting blood hemostasis are divided into three categories: agents who interfere with portions 
Table 5. Experimental inhibitory activity $\left(\mathrm{IC}_{50}, \mu \mathrm{M}\right)$ of calix[4]arene phosphonous acids $\mathbf{9}, \mathbf{1 0}, \mathbf{1 7}, \mathbf{2 5 - 2 9}, \mathbf{3 0 a}, \mathbf{b}$ as inhibitors of PTP1B and other protein tyrosine phosphatases.

\begin{tabular}{ccccccc}
\hline Inhibitor & PTP1B & TC-PTP & PTP $\beta$ & CD45 & SHP2 & LAR \\
\hline $\mathbf{9}$ & $1.2 \pm 0.2$ & $9.3 \pm 1.9$ & $13 \pm 1$ & $5.7 \pm 0.9$ & $1.8 \pm 0.5$ & $>100$ \\
$\mathbf{1 7}$ & $2.5 \pm 0.2$ & $4.9 \pm 1.5$ & $32 \pm 7$ & $22 \pm 6$ & $2.6 \pm 0.6$ & $>100$ \\
$\mathbf{2 5}$ & $1.9 \pm 0.2$ & $27 \pm 6$ & $18 \pm 1$ & $8.4 \pm 2.1$ & $3.4 \pm 0.3$ & $\geq 100$ \\
$\mathbf{2 6}$ & $8.3 \pm 1.1$ & $22 \pm 2$ & $12 \pm 2$ & $59 \pm 10$ & $9.2 \pm 0.4$ & $>100$ \\
$\mathbf{2 7}$ & $1.6 \pm 0.4$ & $11 \pm 3$ & $3.5 \pm 0.7$ & $4.5 \pm 0.9$ & $0.64 \pm 0.15$ & $>100$ \\
$\mathbf{1 0}$ & $8.4 \pm 2.1$ & $59 \pm 14$ & $17 \pm 4$ & $45 \pm 11$ & $7.6 \pm 1.9$ & $>100$ \\
$\mathbf{2 8}$ & $3.2 \pm 0.4$ & $27 \pm 3$ & $32 \pm 4$ & $11 \pm 3$ & $40 \pm 6$ & $72 \pm 5$ \\
$\mathbf{2 9}$ & $6.7 \pm 0.2$ & $51 \pm 10$ & $30 \pm 10$ & $16 \pm 3$ & $53 \pm 5$ & $56 \pm 3$ \\
$\mathbf{3 0 a}$ & $0.34 \pm 0.07$ & $5.2 \pm 1.4$ & - & - & $3.60 \pm 0.85$ & - \\
$\mathbf{3 0 b}$ & $0.32 \pm 0.03$ & $2.8 \pm 0.5$ & & - & $3.8 \pm 0.9$ & - \\
\hline
\end{tabular}

of the coagulation cascade (anticoagulants), agents, which interfere with platelet activation and aggregation (antiplatelet drugs) and agents, which promote disintegration of blood clots (thrombolytics). Currently available anticoagulant drugs are limited to the heparin-like compounds, which are active only when given intravenously, and to the oral coumarin drugs. Heparin is an endogenous polysulfonated glycosaminoglycan which serves as catalyst for the reaction between antithrombin and various activated factors in the coagulation cascade. But, both heparin and coumarin drugs are limited in their usefulness by their hemorrhagic potential, because effective antithrombotic doses of these drugs also concomitantly produce excessive systemic anticoagulation.

The effect on fibrin polymerization of calixarene tetrakis-methylene-bisphosphonic acid $\mathbf{3 1}$ was studied in two kinds of assay. ${ }^{[20]}$

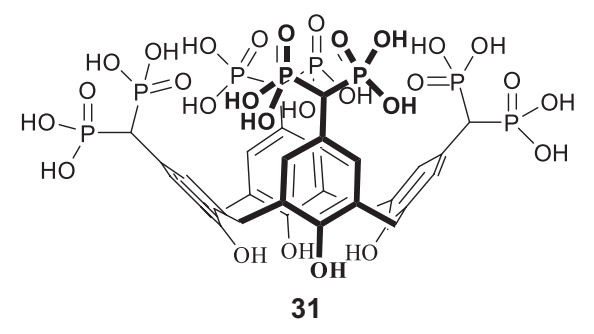

Turbidity analysis showed that $\mathbf{3 1}$ decreased the maximum rate of fibrin polymerization in the thrombin-fibrinogen reaction by $50 \%$ at a molar ratio of compound to starting fibrinogen of 1.7:1 (Figure 8). The lag-time was also increased strongly in the presence of $\mathbf{3 1}$, indicating either a decrease of the rate of protofibril formation or, conceivably, an increase of protofibril critical length (Figure 8B). Similar
A

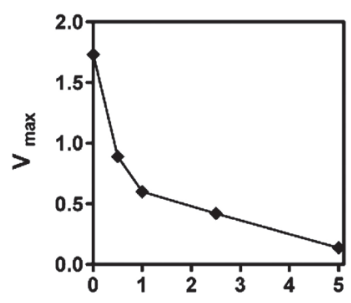

[31] $10^{-6} \mathrm{M}$
$B$

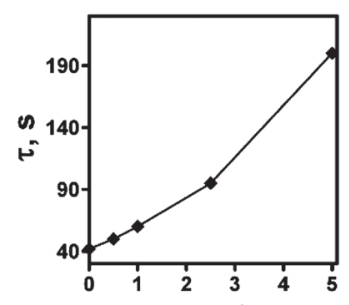

$[31] \cdot 10^{-6} \mathrm{M}$
C

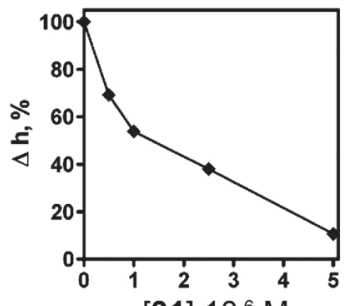

[31] $10^{-6} \mathrm{M}$

Figure 8. Turbidity analysis of the influence of $\mathbf{3 1}$ on fibrin polymerization in the fibrinogen + thrombin reaction. The dependence on calixarene 31 concentration is shown for: $A$ - the maximum rate of fibrin polymerization $\mathrm{V}_{\max } ; B$ - the lag-time $\tau$; $C$ - the final turbidity of fibrin clots $\Delta \mathrm{h}$.

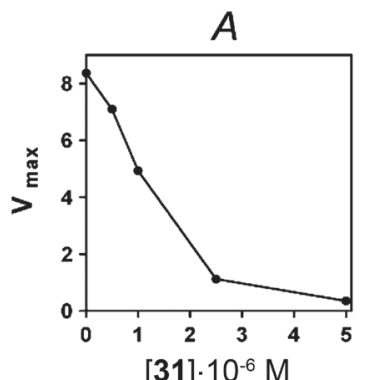

$[31] \cdot 10^{-6} \mathrm{M}$

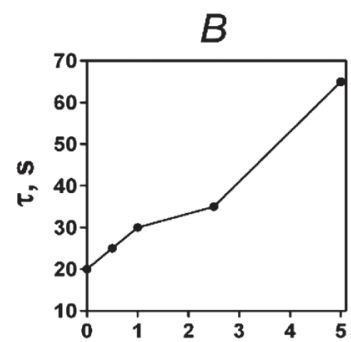

$[31] \cdot 10^{-6} \mathrm{M}$

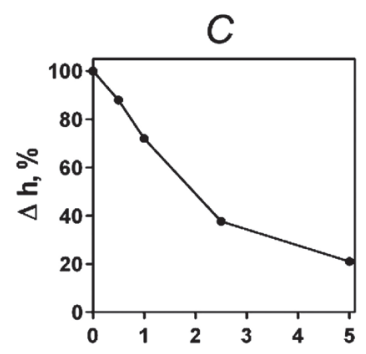

$[31] \cdot 10^{-6} \mathrm{M}$

Figure 9. Turbidity analysis of the influence of $\mathbf{3 1}$ on fibrin desAB polymerization. The dependence on calixarene $\mathbf{3 1}$ concentration is shown for: $A$ - the maximum rate of fibrin polymerization $V_{\max } ; B$ - the lag-time $\tau$, and $C$ - the final turbidity of fibrin clots $\Delta \mathrm{h}$. 
results were obtained when calixarene $\mathbf{3 1}$ inhibited the reassociation of dispersed desAB fibrin (Figure 9), in this case, $\mathrm{IC}_{50}=1.26 \cdot 10^{-6} \mathrm{M}$. Electron microscopy confirmed that $\mathbf{3 1}$ inhibits the first stage of fibrin polymerization (i.e. the formation of protofibrils).

It is of interest that the inhibitory activity of $\mathbf{1 7}$, which has the two methylene bisphosphonic acid substituents, is much less (Table 6) $\left(\mathrm{IC}_{50}=1.31 \cdot 10^{-4} \mathrm{M}\right.$, indicating that the calixarene scaffold and the number of phosphoryl groups in the molecule play a crucial role in the inhibitory effect.

Table 6. Concentration values of compounds that cause $50 \%$ inhibition of the maximum rate of the polymerization of fibrin produced in the fibrinogen + thrombin reaction.

\begin{tabular}{cc}
\hline Compound & $\mathrm{IC}_{50}$ \\
\hline $\mathbf{3 1}$ & $1.26 \cdot 10^{-6} \mathrm{M}$ \\
$\mathbf{1 7}$ & $1.31 \cdot 10^{-4} \mathrm{M}$ \\
$\mathbf{1 8}$ & $0.72 \cdot 10^{-4} \mathrm{M}$ \\
$\mathbf{1 9}$ & $>1.00 \cdot 10^{-4} \mathrm{M}$ \\
\hline
\end{tabular}

Probably, this inhibition is a result of the blocking of site 'A' (Aa17-19, GlyProArg) by the calixarene in a 'knob-hole' manner. HPLC study ${ }^{[21]}$ of the complex formation between 31 and the synthetic peptide Gly-Pro-Arg-Pro, a synthetic analogue of the A knob was carried out. The association constants of calixarene $\mathbf{3 1}$ complexes with amino acids Gly, Pro, Arg and tetrapeptide Gly-Pro-Arg-Pro in a methanolwater mobile phase $(50: 50, \mathrm{v} / \mathrm{v})$ presented in Table 7 . The highest association constant $3395 \mathrm{M}^{-1}$, is observed for tetrapeptide Gly-Pro-Arg-Pro. Analysis of the dependence of peptide retention time on the calixarene concentration in the mobile phase indicates 1:1 ratio of the host and guest in the complex.

Table 7. The association constants of calixarene $\mathbf{3 1}$ with amino acids and tetrapeptide.

\begin{tabular}{cc}
\hline Guest & $K_{\mathrm{A}}, \mathrm{M}^{-1}(\mathrm{RSD}, \%)$ \\
\hline Gly & $280(10)$ \\
Pro & $814(26)$ \\
Arg & $2576(21)$ \\
Gly-Pro-Arg-Pro & $3395(19)$ \\
\hline
\end{tabular}

Furthermore, calixarene $\mathbf{3 1}$ doubles both the PT and APTT in normal human blood plasma at concentrations of $7.13 \cdot 10^{-5} \mathrm{M}$ and $1.10 \cdot 10^{-5} \mathrm{M}$, respectively.

In vivo studies demonstrated ${ }^{[22]}$ that $\mathbf{3 1}$, being injected intravenously into rabbit's bloodstream, acts as effective anticoagulant agent and its effects correspond to those shown in vitro (Table 8). According to the results calix[4] arene 31 can be considered as a potential anti-thrombotic agent with narrow effect range.

Direct study of $\mathbf{3 1}$ action on endothelial cells was carried-out using PAE cell culture that was synchronized in G0/G1 phase of cell cycle. ${ }^{[23]}$ However, cell culture studies demonstrated antiapoptotic and proliferation-stimulating effects of $\mathbf{3 1}$ on PAE (Table 9).

Fast decrease of platelets count by $\mathbf{3 1}$ could provide additional anticoagulant effect but on the other hand it
Table 8. Clotting potential (CP), haemostasis potential (HP), fibrinolytic potential (FP) and ratios of Clotting and Fibrinolytic potentials $(\mathrm{CP} / \mathrm{FP})$ in rabbit plasma before $(0)$, and 2 and $4 \mathrm{~h}$ after an IV injection of $\mathbf{3 1}$

\begin{tabular}{cccccc}
\hline $\begin{array}{c}\text { Time after } \\
\text { injection, } h\end{array}$ & CP & HP & FP & CP/FP & Clot half-life time, h \\
\hline 0 & 91.8 & 64.9 & 26.9 & 0.29 & 740 \\
2 & 53.4 & 41.4 & 12 & 0.22 & 740 \\
4 & 8.8 & 5.7 & 3.1 & 0.35 & 550 \\
\hline
\end{tabular}

Table 9. Density of apoptotic cells and distribution of endothelial cells in the presence of $\mathbf{3 1}(300 \mu \mathrm{M})$.

\begin{tabular}{ccccc}
\hline & Apoptotic & \multicolumn{3}{c}{ Cell cycle stages } \\
\cline { 3 - 5 } & cells, \% & $\mathrm{G}_{0} / \mathrm{G}_{1}$ & $\mathrm{G}_{2} / \mathrm{M}$ & $\mathrm{S}$ \\
\hline Control & $24.0 \pm 2.1$ & $85.71 \pm 2.30$ & $4.85 \pm 0.50$ & $9.71 \pm 0.70$ \\
$\mathbf{3 1}$ & $19 \pm 1$ & $34.13 \pm 1.40$ & $33.19 \pm 1.80$ & $32.68 \pm 1.30$ \\
\hline
\end{tabular}

made obligatory the instant control of platelet viability during treatment with $\mathbf{3 1}$ and, possibly, concomitant therapy targeted to platelet restoration.

Intravenous administration of $\mathbf{3 1}$ did not affect endothelial cells that was confirmed by determining the level of tPA which is the marker of endothelial activation. However, the study of $\mathbf{3 1}$ effects on endothelial cells culture allowed to conclude anti-apoptotic and proliferation-stimulating effects of 31 that could be promising during revascularization of tissues after ischemia.

\section{Antibacterial Properties of Calixarenes}

The antibacterial and antibiofilm activities of several amphiphillic tetracationic calixarenes functionalized with methylimidazolium 32a,b, choline 33a,b and $N, N$ dimethyl- $N$-(2-aminoethyl)ammonium $\mathbf{3 4 a}, \mathbf{b}$ groups were tested and revealed that their MIC values are close to those of antibiotics and better or equal to those of QAS (Table 10). Obtained results demonstrated the clear dependence of antibacterial activity from the alkyl chain length on the lower rim of calixarene. Tetrapropoxycalixarenes have 10-50 times higher antibacterial activity than tetraoctylcalixarenes with the same cationic residues on the upper rim. The nature of the cationic groups at their macrocycle upper rim, defines their mode of interaction with bacterial membrane structures. Calixarene 32a grafted with more lipophillic and planar methylimidazolium groups showed the best activity among all investigated calixarenes. At the same time, tetrapropoxycalixarene 34a shows high inhibitory activity against Staphylococcus aureus biofilms. ${ }^{[24]}$ Another deep investigation of calixarenes 33a,b also confirmed previously described results. ${ }^{[25]}$

\section{Calixarene-based Nanoparticles for Gene Transfection and Bio-Imaging}

A series of amphiphilic calixarenes 32b, 33a-d, 34b bearing cationic groups at the upper rim and the alkyl chains at the lower rim were synthesized. ${ }^{[26-28]}$ The molecular design 


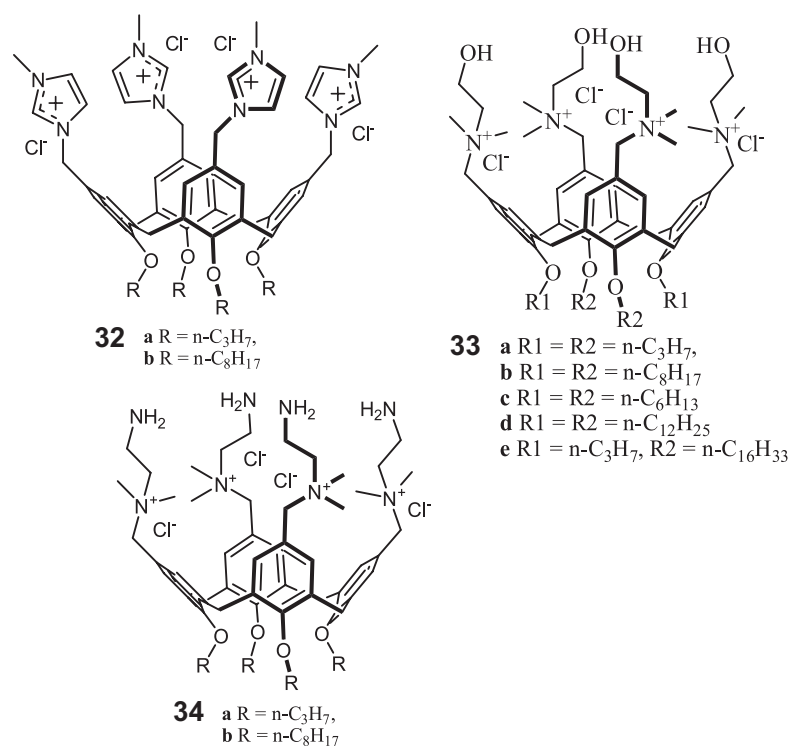

Table 10. MIC values of calixarenes 32a-34a, $\mu \mathrm{g} \cdot \mathrm{mL}^{-1}(\mu \mathrm{M})$.

\begin{tabular}{|c|c|c|c|c|}
\hline Calixarene & $\begin{array}{c}\text { S. aureus } \\
\text { ATCC } 6538\end{array}$ & $\begin{array}{c}\text { P. aeruginosa } \\
\text { ATCC } 9027\end{array}$ & $\begin{array}{c}\text { K. pneumoniae } \\
\text { ATCC } 10031\end{array}$ & $\begin{array}{l}\text { E. coli } \\
\text { ATCC } \\
25922\end{array}$ \\
\hline $32 a$ & $\leq 10(\leq 9)$ & $50(45)$ & $\leq 10(\leq 9)$ & $\leq 10(\leq 9)$ \\
\hline $33 a$ & $\leq 10(\leq 9)$ & $1000(870)$ & $100(90)$ & $100(90)$ \\
\hline $34 a$ & $\leq 10(\leq 5)$ & $50(26)$ & $500(260)$ & $500(260)$ \\
\hline
\end{tabular}

of these calixarenes was directed to increase their affinity for DNA (compared to 35-39 ${ }^{[29]}$ ) due to formation of the additional hydrogen bonds between the hydroxyl group of choline residues and the carbohydrate and phosphate groups of DNA in the case of $\mathbf{3 3}$ or additional electrostatic interaction between protonated aminogroups of $\mathbf{3 4 \mathbf { b }}$ and phosphate groups of DNA or to improve $\pi$-stacking interaction with the nucleic bases of DNA in the case of $\mathbf{3 2} \mathbf{b}$.

The effect of the length of aliphatic chains and the head group structure on their self-assembly, interaction with DNA, properties of their DNA complexes, the transfection efficiency and cytotoxicity were studied. Calixarene amphiphiles 32-34 form micelles of 6-9 nanometers in water solutions. Such micelles bind to negatively charged DNA surfaces and compensate their charges. Gene transfection experiments were performed in HeLa and COS-
7 cells. It was found that longer alkyl chains favor formation of remarkably small sizes $\sim 40 \mathrm{~nm}$ particles with plasmid DNA. These nano-aggregates are characterized by higher transfection efficiency and lower cytotoxicity.

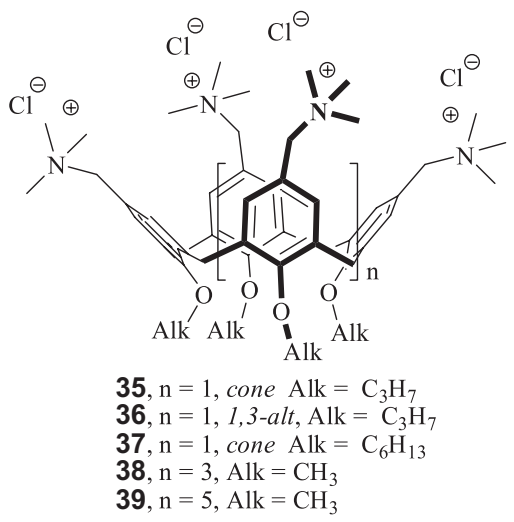

The most promising results are observed for 33d-DOPE complex at N/P 2 ratio, which shows much higher rate of transfected cells $(\sim 80 \%)$ compared to 33b $(\sim 36 \%)$ and even to jetPEI ( $70 \%)$, which is one of the most efficient transfection agents. The rate of transfected cells grows in the following order: 33a $<34 \mathbf{3} b<\mathbf{3 3 c}<\mathbf{3 2} \mathbf{b}<\mathbf{3 3 e} \sim \mathbf{3 3 b}<\mathbf{3 3 d}$. In the presence of serum only 33d molecule showed detectable transfection among the studied calixarenes. Moreover, 33d was the only calixarene that showed detectable transfection without DOPE. Thus, long alkyl chains and the largest hydrophobic domain of $\mathbf{3 3 d}$ improve significantly the transfection efficiency. On the other hand, presence of four additional amino groups, which could be protonated at $\mathrm{pH}<7$ affected only stoichiometry of the complexes with DNA without affecting their transfection efficiency or cytotoxicity. The obtained results provide new insights for designing new artificial viruses based on macrocyclic molecules.

Stable nanoparticles with a diameter of $7 \mathrm{~nm}$, coated with chemically bound fragments of fluorescent cyanine dyes (Figure 11) were synthesized on the basis of cationic amphiphilic calixarene $\mathbf{4 0}$ with reactive acetylene groups. ${ }^{[30]}$ The nanoparticles are characterized by a maximum of fluorescence in the region of $550 \mathrm{~nm}$. They are twice as bright as the commercial cadmium-telluric nanoparticles QD585 , which are used as biomarkers. An example of a HeLa

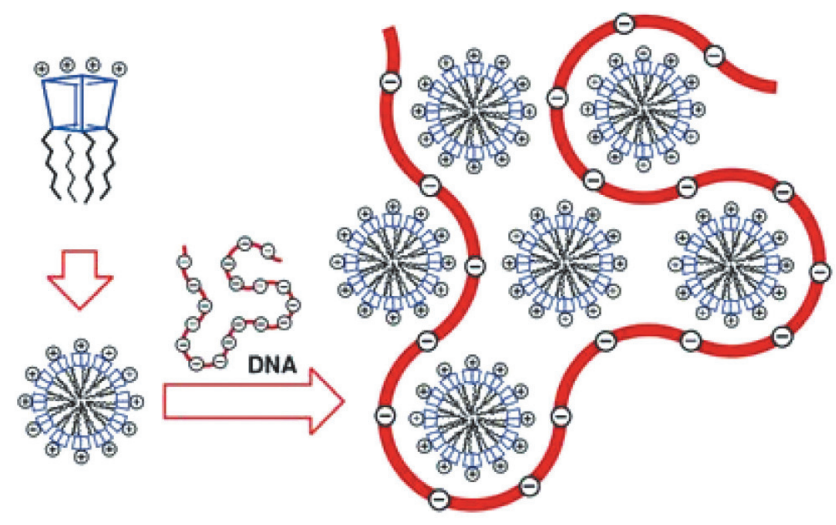

Figure 10. A schematic representation of the binding of polycationic calixarene (33b) to a DNA molecule. 


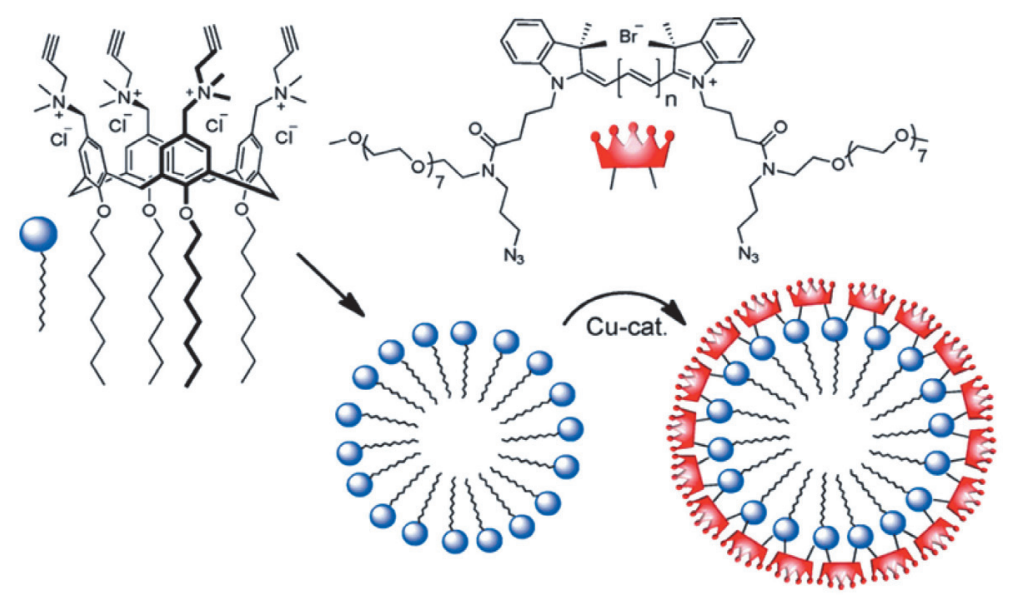

Figure 11. Scheme of synthesis of fluorescent calixarene nanoparticles.

biological cell shows that nanoparticles penetrate biological membranes, selectively accumulate only in certain areas of the cell and stain them. These nanoparticles can be used as markers in cytological and histological studies, as well as in molecular biochemistry.

\section{Conclusion}

Nano-sized calixarene-based macrocycles, functionalized with various bio-affine groups were synthesized and investigated. Systematic experimental study of these calixarenes showed their broad spectrum of bio-activity. Sulfonylamidine calixarenes selectively inhibit active transport of $\mathrm{Ca}^{2+}$ in smooth muscle cells due to binding to $\mathrm{Ca}^{2+}, \mathrm{Mg}^{2+}$-ATPase of plasmatic membrane. Modification of the calixarene upper rim by the hydroxyphosphonous and aminophosphonous acid groups leads to specific highly effective inhibitors of $\mathrm{Na}^{+}, \mathrm{K}^{+}$-ATPase (Sodium-Potassium exchanger) plasmatic membrane of the same cells. On the other hand, calixarenes modified by amide groups, especially amidochalcone moieties effectively stimulate accumulation of $\mathrm{Ca}^{2+}$ in mitochondria of smooth muscle cells. Hydroxy-, amino-, methylene-bis- and hydroxymethylene-bisphosponic acid derivatives of (thia)calixarenes efectively and enantio selectively bind to various alkaline phosphatases, glutathione transferase, and protein tyrosine phosphatase $1 \mathrm{~B}$ and block their catalytic action. Calixarene modified with four methylene-bisphosphonic acid groups due to formation of strong complex with Gly-ProArg-Pro tetrapeptide effectively inhibits fibrin polymerization and act as anthitrombotic agent in vivo. Polycationic water-soluble calixarenes showed good antibacterial properties often better than quaternary ammonium compounds used in medicine as antiseptics. Amphiphilic polycationic calixarenes form the micelle-like particles in water with diameter of $6 \mathrm{~nm}$. These particles can bind DNA, compact and transport it into living cells promoting transfection. On the other hand, chemical stabilization of these nanoparticles with fluorescent cyanine dyes leads to formation useful instrument for bio-imaging (diagnostic) and target drug delivery.
Acknowledgements. The authors thank Professors S.O Kosterin, T.V. Lugovskoy, S.V. Komisarenko, A.I. Vovk, Y. Mely and HDR A.S. Klymchenko for their great contribution to the Bio-Calix project and for helpful discussions.

\section{References}

1. Calixarenes in the Nanoworld (Vicens J., Harrowfield J., Eds.), Dordrecht: Springer, 2007.

2. Calixarenes and Beyond (Neri P., Sessler J.L., Wang M.-X., Eds.), Switzerland: Springer, 2016.

3. Rodik R.V., Boyko V.I., Kalchenko V.I. Front. Med. Chem. 2016, 8, 206-301.

4. Rodik R.V., Boyko V.I., Danylyuk O.B., Suwinska K., Tsymbal I.F., Slinchenko N.V., Babich L.G., Shlykov S.O., Kosterin S.O., Lipkowski J., Kalchenko V.I. Tetrahedron Lett. 2005, 46, 7459.

5. Labyntseva R.D., Slinchenко N.M., Veklich T.O., Rodik R.V., Cherenok S.O., Boyko V.I., Kalchenko V.I., Kosterin S.O. Ukr. Biochem. J. 2007, 79, 44-54.

6. Veklich T.A., Shkrabak A.A., Slinchenko N.N., Mazur I.I., Rodik R.V., Boyko V.I., Kalchenko V.I., Kosterin S.A. Biochemistry 2014, 79, 417-424.

7. Veklich T.O., Kosterin S.O., Rodik R.V., Cherenok S.O., Boyko V.I., Kalchenko V.I. Ukr. Biochem. J. 2006, 78, 70-86.

8. Veklich T.O., Shkrabak O.A., Kosterin S.O., Rodik R.V., Cherenok S.O., Boyko V.I., Kalchenko V.I. Ukr. Biochem. J. 2006, $78,53-63$.

9. Veklich T.O., Shkrabak A.A., Cherenok S.O., Kalchenko V.I., Kosterin S.O. Ukr. Biochem. J. 2012, 84, 49-57.

10. Klyachina M.A., Boyko V.I., Yakovenko A.V., Babich L.G., Shlykov S.G., Kosterin S.O., Khilya V.P., Kalchenko V.I. J. Inclusion Phenom. 2008, 60, 131-137.

11. Bevza A.A., Labintseva R.D., Rodik R.V., Cherenok S.O., Kosterin S.O., Kalchenko V.I. Ukr. Biochem. J. 2009, 81, 49-58.

12. Vovk A.I., Kalchenko V.I., Cherenok S.A., Kukhar V.P., Muzychka O.V., Lozynsky M.O. Org. Biomol. Chem. 2004, 2, 3162-3166.

13. Cherenok S., Vovk A., Muravyova I., Shivanyuk A., Kukhar V., Lipkowski J., Kalchenko V. Org. Lett. 2006, 8, 549-552.

14. Vovk A.I., Kononets L.A., Tanchuk V.Yu., Cherenok S.O., Drapailo A.B., Kalchenko V.I., Kukhar V.P. Bioorg. Med. Chem. Lett. 2010, 20, 483-487.

15. Koren S., Fantus I.G. Best Pract. Res. Clin. Endocrinol. Metab. 2007, 21, 621-640. 
16. Trush V.V., Cherenok S.O., Tanchuk V.Yu., Kukhar V.P., Kalchenko V.I., Vovk A.I. Bioorg. Med. Chem. Lett. 2013, 23, 5619-5623.

17. Trush V.V., Tanchuk V.Y., Cherenok S.O., Kalchenko V.I., Vovk A.I. Journal of Organic and Pharmaceutical Chemistry 2014, 12, 39-42.

18. Trush V., Cherenok S., Tanchuk V., Kalchenko V., Vovk A. Chem. Biol. Lett. 2015, 2, 1-5.

19. Vovk A., Trush V., Kharchenko S., Tanchuk V., Kalchenko V. Org. Biomol. Chem. 2015, 13, 8803-8806.

20. Lugovskoy E.V., Gritsenko P.G., Koshel T.A., Cherenok S.O., Kalchenko V.I., Komisarenko S.V. FEBS J. 2011, 278, 1244-1251.

21. Kalchenko O.I., Lipkowski J., Kalchenko V.I., Vysotsky M.A., Markovsky L.N. J. Chrom. Sci. 1998, 36, 269-273.

22. Chernyshenko V.O., Korolova D.S., Dosenko V.E., Pashevin D.O., Kalchenko V.I., Pirogova L.V., Chernyshenko T.M., Lugovska O.E., Kravchenko N.A., Makogonenko Y.M., Lugovskoy E.V., Komisarenko S.V. Pharm. Anal. Acta 2015, 6:406.

23. Chernyshenko V.O., Korolova D.S., Nikolaienko T.V., Dosenko V.E., Pashevin D.O., Kalchenko V.I., Cherenok S.O.,
Khranovska N.N., Garmanchuk L.V., Lugovskoy E.V., Komisarenko S.V. Biotechnologia Acta 2016, issue 3, 37-43.

24. Melezhyk I.O., Rodik R.V., Iavorska N.V., Klymchenko A.S., Mely Y., Shepelevych V.V., Skivka L.M., Kalchenko V.I. Anti-Infective Agents 2015, 13, 87-94.

25. Ukhatskaya E., Kurkov S.V., Hjálmarsdóttir M.A., Karginov V.A., Matthews S.E., Rodik R.V., Kalchenko V.I., Loftsson T. Int. J. Pharm. 2013, 458, 25-30.

26. Mchedlov-Petrossyan N.O., Vilkova L.N., Vodolazkaya N.A., Yakubovskaya A.G., Rodik R.V., Boyko V.I., Kalchenko V.I. Sensors 2006, 6, 962-977.

27. Rodik R.V., Klymchenko A.S., Jain N., Miroshnichenko S.I., Richert L., Kalchenko V.I., Mély Y. Chem. Eur. J. 2011, 17, 5526-5538.

28. Rodik R.V., Anthony A.-S., Kalchenko V.I., Mély Y., Klymchenko A.S. New J. Chem. 2015, 39, 1654-1664.

29. Shi Y., Schneider H.J. J. Chem. Soc., Perkin Trans. 2 1999, 1797-1803.

30. Shulov I., Rodik R.V., Arntz Y., Reisch A., Kalchenko V.I., Klymchenko A.S. Angew. Chem. Int. Ed. 2016, 55, 15884-15888.

Received 27.11.2017

Accepted 03.12.2017 